\title{
Linkage Between Political Parties and Constituents in Malang Raya, Indonesia
}

\author{
Budhy Prianto* Dwi Suharnoko \\ Department of Public Administration, Faculty of Social and Political Sciences, University of Merdeka Malang, \\ Jl. Terusan Dieng No. 62-64 Malang, Indonesia
}

\begin{abstract}
In the last two decades, prestige of political parties in developed countries plummeted. This phenomenon was characterized by decline in constituent support for political parties, which led to establishment independent political movements. This also occurred in Indonesia. Objective of this study was to obtain capture and explain the typology of linkage between political parties and constituents in Malang Raya in the 2009 and 2014 Legislative and Regional Head elections based on Thomas Poguntke and Kenneth M Roberts's typology. It employed a qualitative approach and involved four largest political parties in Malang Raya as the objects. The analysis method adopted Creswell's. The findings showed that Indonesian Democratic Party-Struggle (PDI-P), Democratic Party (PD) and Functional Groups Party (Partai Golkar) had clientelist linkages type, while National Awakening Party (PKB) had encapsulating linkages type. The four dominant parties had programmatic linkages type. PKB and PDI-P had both personalistic linkages and charismatic bonds type, while PD was the only political party with marketing linkages type.
\end{abstract}

Keywords: democracy; linkage; political party; constituent; support; general elections

DOI: $10.7176 / \mathrm{PPAR} / 12-1-02$

Publication date: January $31^{\text {st }} 2022$

\section{Introduction}

Malang Raya is an area comprises three local governments, namely Malang City, Malang Municipality and Batu City. Some people argue that "Malang Raya" is cultural representation of the former Malang residency which included Malang Municipality, Malang City, Batu City, Probolinggo (both City and Municipality), Pasuruan (both City and Municipality, and Lumajang Municipality. In later years "Malang Raya" referred to Malang Municipality, Batu City, Malang City and some parts of Pasuruan Municipality where natives are called "Arek Malang" or "Arema", in short (http://cakmaryono.com/malang-raya/).

Observation towards political context in Malang Raya, particularly one related to the process of articulation and aggregation of public interests resulted in an interesting phenomenon. Malang Raya residents, approximately 3.5 million people in total, have a diverse and fluctuating political representation. It can be inferred based on seats acquisition of the parties in the three regions of Malang Raya in the 2009 and 2014 legislative elections. Table 1 showed numbers of seats seventeen political parties in the area acquired in the legislative elections.

Based on the table, seat acquisition of Indonesian Democratic Party-Struggle (Partai Demokrasi IndonesiaPerjuangan / PDI-P), Functional Groups Party (Partai Golkar), and National Awakening Party (Partai Kebangkitan Bangsa / PKB) in the three areas of Malang Raya was relatively stable. It means that the political parties had a good linkage with both the constituent and their voters. At the opposite, seat acquisition of Democratic Party (Partai Demokrat / PD), Great Indonesia Movement Party (Partai Gerindra), Prosperous Justice Party (Partai Keadilan Sejahtera / PKS), National Mandate Party (Partai Amanat Nasional / PAN), and People's Conscience Party (Partai Hati Nurani Rakyat / Hanura) in the Regional House of Representatives was fluctuating, which occurred due to a shift in the support of constituent to the parties. There are even a number of political parties that only existed in the 2009 elections, such as the Indonesian National Marhaenism Party (Partai Nasional Indonesia Marhaenisme (PNIM), Patriotic Party (Patriot Party / PP), National Front Party (Partai Barisan Nasional / PBN), and Functional Care for Nation Party (Partai Karya Peduli Bangsa / PKPB) were the political parties that could not survive after the 2009 election. As an addition, the Indonesian Justice and Unity Party (Partai Keadilan dan Persatuan Indonesia / PKPI) only acquired a seat in Batu City.

The second is related to regional head election and its results. Sujud Pribadi, candidate from PDI-P, was elected as Malang Regent for two consecutive periods (2001-2005 and 2005-2010). However, the Regent of Malang in the following period was the candidate from Golkar and PKB. Peni Suparto, the Mayor of Malang between 2003 and 2013 was another candidate of PDI-P. However, similar to Malang Regency, in the 2014 Regional Head Election, PDI-P candidate lost to candidate of PKB. In Batu City, PDI-P is the dominant party for three consecutive periods. Edy Rumpoko, one of its candidates, was elected as Mayor of Batu for two consecutive periods (2007-2012 and 2012-2017). His successor, Dewanty Rumpoko is also a candidate from PDI-P.

Empirically, it is predicted that 2004 Act Number 32 on Regional Government contributed to fluctuating support, including a shift, of constituent toward political parties. In terms of regional head election (Governor, 
Regent and Mayor), the act conveyed two important facts on linkage between political parties and constituent (Article 56 and 59). First, regional head election was carried out based on the principles of democracy, which later is translated into direct voting by the society. Second, candidate referred to regional head and vice regional head candidates supported by political party or coalition of political parties acquiring $15 \%$ chairs in Regional House of Representatives or from accumulated valid votes from the previous legislative election. The direct voting system was conducted for the first time on June 1, 2005.

The researcher argued that there are two factors that caused fluctuating or shift in constituent support toward political party in the 2009 and 2014 legislative elections, which resulted in seat acquisition in Regional House of Representatives, and PDI-P winning streak in election of Regent of Malang in 2010 and 2015, Mayor of Malang in 2013 and Mayor of Batu in 2017. The first is in exercising their voting rights, constituent leans toward candidates rather than political party where candidate is affiliated in. The second is the fluctuation and shift indicated that political party program did not work effectively or in other words, the linkage between political party and constituent is poor.

Based on the explanation above, this study aimed to describe and explain phenomenon related to linkage between political parties and their constituents in Malang Raya in the 2009 and 2014 direct legislative and regional head election.

\section{Literature Review}

\subsection{State of the art}

In a theoretical context, the role of political parties cannot be replaced by any institution, even elements of civil society or other organizations that represent the public interest. Political parties connect government institutions with elements of civil society and its constituents. Political parties organize various ideological differences and interests in society. Political parties have a pivotal role toward democratic life, and thus, many political scientists claimed that no single political system can take place without a political party (Norris, 2005; Macridis, 1998; Shively, 1991; Budiardjo, 2008).

However, an interesting phenomenon occurred in the 21 st century. In Europe, there has been a decline in membership of political parties in large and small democratic countries, both old and new (Biezen et al., 2012). The deterioration of constituent support affects not only new parties, but also established parties (Drummond, 2006). Mack (2010) who conducted research in the United States, Canada, England, and Italy, stated that there were disalignments in a number of parties, even to the point of suspicion of the death of political parties.

Development of corporatism-which resulted in the diversion of the attention of political elites from voters/constituents to market actors (Ezrow and Hellwig, 2014) - and electronic media were seen as the cause of the decline in linkage between parties and constituents. This has also been seen as the cause of the emergence of new political movements (Selle and Svasand, 1991; also Heidar and Sagle, 2003). Even Chadwick and StromerGalley (2016) stated that the power of digital media in forming forces outside political parties has resulted in the demise of political party organizations. In the case of Estonia, a phenomenon such as by Ehin and Solvak (2012) is said to be an anti-party attitude which then encourages the emergence of independent candidates in the elections for the European Parliament in Estonia. In the latest case, the election of independent candidate Emmanuel Macron as the new president of France (Tempo, 21 May 2017) is also a manifestation of such an antiparty political movement.

This phenomenon, taking place in Europe, has also spread to Indonesia. Since the direct presidential elections in September 2004, the prestige of political parties and their leaders has declined (Mas'oed, 2004). New political parties were established and independent candidates from outside political parties can participate in regional head election. 2008 Act Number 12 of 2008 on Second Amendment to 2004 Act Number 32 on Regional Government and 2015 Act Number 8 on Election of Governors, Regents and Mayors are integral factors in declining influence of political parties for constituents (see Prianto and Noorsetya, 2016).

\subsection{Role and function of political party}

Article 10 (2) of 2011 Act Number 2 on Amendment to 2008 Act Number 2 on Political Party stated that objectives of political party are: a. to increase political participation of its members and society in implementation of political and government activities; b. to realize vision and missions of political party; and c. develop political ethics and culture among the nations and its people. Theoretically, Dalton et al (2011) stated that "political parties emerged as the primary linkage mechanism for facilitating the representative process."

Theoretically, the functions of political parties are: a) a basic for the mobilization of masses of citizens; b) a means of recruiting and socializing political leaders; c) structured political identity, at both the masses and elite levels; d) a method of control within a government structure; e) a means of interest expression and articulation; and f) a basic of supportive function (Shively, 1991; Budiardjo, 2008; Macridis, 1988). 


\subsection{Linkage between political parties and constituent}

Macridis (1988) identified party typology into: authoritarian and democratic; integrative and representative; ideological and pragmatic; religious and secular; democratic and revolutionary; mass and elite; democratic and oligarchic. On the other hand, Gunther dan Diamond (2003) categorized it into five types, namely elite-based parties; mass-based parties; ethnicity-based parties; electoralist parties; and movement parties.

Focusing on parties with high representation and participation, Mack (2010) stated that such parties are the most successful ones in elections. However, they are the most susceptible to attacks by division. Mack identified the parties into six types, some of which have also been identified by either Macridis or Gunther and Diamond. Mack's typology of parties is: elite or cadre parties; mass parties; catch-all parties; cartel-parties; business-firm parties; and parties in service. It focuses more on parties with a large representation and participation; this typology emphasized on linkage between political parties and constituents.

The classical political science literature classified non-governmental organizations, to whichever category they belong, as interest groups and pressure groups (Shively, 1991). Non-governmental organizations together with political parties refer to a functional structural approach, in their position as a political infrastructure. Both of them play a role in connecting society and the government in terms of formulating public decisions. Both have the function of articulating interests (Almond, 1974; Cumming, Jr and Wise, 1981). One of the findings of Prianto (2010) who conducted a study entitled Linkage Between Political Parties and Non-Governmental Organizations in Malang City revealed that that, in various degrees, all political parties have linkage to nongovernmental organizations in empowering and increasing community political participation. Related to this role, Dalton et al. (2011) explained that that "parties need votes to survive, which brings us to their participation linkage". Strong linkage between each chain of party government enables the government to serve as a means of linking citizen interests to government output. However, poor linkage will result in deteriorating party government model.

A more contemporary study by Poguntke (2002), for example, proposed similar findings. In his paper entitled Party Organizational Linkage, Poguntke argued that generally there are two lines of linkage between political parties and society. The first is direct linkage, in which party elite utilized mass media, political marketing techniques, and direct personal communication such as mail, email, and the internet. It does not occur in an aggregation process; the only thing that emerges is personal relationships between voters and party elites. The second is organizational linkage, where parties select/articulate interests and aggregate interests without involving party elites; it prefers organizations such as trade organizations, religious organizations, or youth organizations that the party owned. Poguntke postulated that there are three types of organizations that can facilitate linkage and communication between party elites and voters, namely new social movements, collateral organizations, and membership organizations.

In his study on linkage between party and society, and democratic representation in Latin America, Roberts (2014) identified similar phenomena as Poguntke, which he later developed into five linage models. The first is encapsulating linkages that have two specific characteristics, namely mass-based organization, and participatory affiliation. In this model, direct participation of the most in political process aside from voting is instrumental. Thus, it requires construction of organization on the local scale or grass-root units that supply members and permanent followers for political actions. The second is programatic linkages where commitment to political party ideology and program is the basis for loyalty of an individual toward the party. The third is political brokerage and patron-clientelism, patron-client linkage emphasizing on exchange of benefit for political loyalty. The fourth is personalistic linkages and charismatic bonds in which support to political party is based on leadership qualities of prominent figures in the party rather that ideological commitment and organizational identity. The fifth is marketing linkages, developed based on certain purposes of election, for instance to propose popular policies or regulation to attract political interests of swing voters, develop positive image for owned candidates, or communicate negative image of competitors.

\section{Methods}

The study used qualitative-naturalistic approach with phenomenology strategy. Source of primary data was depth-interview with main informants, political elites from four largest parties in Malang Raya, namely Indonesian Democratic Party-Struggle (Partai Demokrasi Indonesia-Perjuangan / PDI-P), Democratic Party (Partai Demokrat / PD), Functional Groups Party (Partai Golongan Karya / Golkar), and National Awakening Party (Partai Kebangkitan Bangsa / PKB). Other informants were voters (constituent) spread across Malang Raya selected based on purposive sampling. Secondary data were obtained from mass-media, Bureau of Statistics of Malang Raya and General Election Commission of Malang Raya. Data analysis and interpretation process adopted Creswell (2010)'s analysis, namely data processing; data display; coding based on theme and description; data classification based on the theme and description; making relation between themes/descriptions; interpretation of the themes /descriptions. 


\section{Findings and Discussion}

\subsection{Linkage between central and regional management in management of local political parties}

Based on the interview, the informants admitted that there are some factors that cause weak linkage between political parties and constituents. These contributing factors were different in each party. An example is every party had dominant figures that had the most control over management of political party, decision-making, policy issuance, political party member recruitment, and legislative and regional head candidacy. As the result, political parties are perceived as an instrument for certain individual to achieve their personal interests. Macridis (1988) and Gunther and Diamond (2003) argued that due to this phenomenon, political party tends to be oligarchic. This results in internal conflict between political elites as well as between political elites and constituents at grassroot level. Andre and Beyens (2013), studying loyalty to political parties and electoral divisions in the UK reported the same phenomenon, oligarchy through representative democracy causes conflicts between political elites and between the elites and constituents.

PD is political party who depend heavily on its figures (elites). Chief of PD of Malang Raya admitted that it was inevitable since Susilo Bambang Yudhoyono (SBY) established PD for his presidential candidacy in 2004. The informant stated that:

"Until today, SBY and PD are inseparable. SBY has strong influence toward all PD programs involving constituents. In our party, figure comes after management. Our expectation is that both factors work simultaneously."

This is shown by the fact that PD acquired 12 seats in the Regional House of Representatives of Malang Raya in 2009 General Election, but only 5 in 2014 General Election. When SBY was elected as President, constituents were influenced greatlyd by the news in mass media. This impacted PD severely. Any policies he and his cabinet had issued had always been responded negatively by the opposition. The effect toward constituent at grass-root level is evident. Mass media did not deliver clear and thorough information to the constituents and as the result, Indonesian people tend to focus more on negative sides of SBY Presidency instead of his achievements. Roberts (2014) defined this type of linkage as political brokerage and patron-clientelism using direct linkage (Poguntke, 2002), where what occurred was patron-client relationship on national-scale and it resulted ineffective party mechanism.

It can be inferred that the constituent's perception of PD was dictated by SBY and his presidency instead performance of the political party. This led to the following question, whether or not PD was a figure a party. One of the chiefs of PD of Malang Raya corroborated by stating that:

"This is inevitable. Even though we have delivered SBY's working program to the constituents, they emphasized more on negative journalism on mass-media. Thus, the constituents were exposed more to information on the figure rather than on the cabinet and government program. We, management, has tried to deliver information on government achievement to counter these negative information hoping that the constituents are exposed to both positive and negative information about PD and SBY. However, our effort was not successful. The media has a stronger influence. As the consequence, our voters plummeted."

As an addition, another political party that depends heavily on political figure was PDIP. The difference lies within Soekarno as the founding father of Partai Nasional Indonesia (PNI) that later was transformed into PDIP, political party whose chief is Megawati Soekarno Putri, Soekarno's daughter. Its influence toward constituent was both Soekarno and Megawati Soekarno Putri were displayed clearly in all means of communication between PDIP and constituent, different from PD that developed direct linkage and poitilical marketing (Poguntke, 2002) or marketing linkage (Robert, 2014), where constituent considered SBY as the central role of these linkages, and thus, a means of communication between PD and constituent. Soekarno had influential role among constituents, so influential that the constituents responded positively to his daughters and son. Responding to that, one of the chiefs of PDIP of Malang Raya stated that:

"As an example, when Megawati is no longer with PDIP, PDIP will still have loyal followers compared to when SBY resigned from PD or Prabowo from Gerindra. However, when PDI-P is no longer associated to Soekarno, the party will lose significant numbers of follower. When Megawati resigned, Prananda will take over his place. Prananda, her son, is a less popular, yet consistent and competent figure of PDIP."

Other chiefs of PDIP also explained that Puan Maharani and Puti Guntur Soekarno were descendants of Soekarno and younger figures in PDI-P. Thus, when Soekarno cannot be associated to PDIP anymore, popularity of this party would decline. Therefore, extended family members of Soekarno should get involved in PDI-P.

PKB is a political party founded by Kyais of Nahdlatul Ulama (NU). Its establishment did not take a long time, considering the Kyais had known each other for a long time. In addition, the Kyais also had a solid relationship with their ummah. Until recently, PKB has maintained a close relationship with the kyais. One of the chiefs of PKB of Malang Raya described relationship between PKB, Nahdlatul Ulama (NU)'s kyais and ummah.

"We are aware that, besides the management, the kyai has a central role in getting votes for PKB in the grass-root levels. PKB, kyai and NU are inseparable units. Thus, on many occasions, Management has 
instructed its cadres, administrators and council members to maintain a close connection with the kyais."

Based on these explanations, PKB cannot be categorized as figure party; instead, it belonged to what Roberts (2014) defined as personalistic linkages and charismatic bonds. Linkage between PKB and constituent did not rely solely on certain individual figures, in and outside its management. The linkage was determined by a number of kyais who have cultural and emotional connection to NU ummah, general constituent of PKB.

Different from the other three parties, Golkar has another type of linkage. The party strength relies within its founding organizations, Sentral Organisasi Karyawan Swadiri Indonesia (SOKSI), Kesatuan Organisasi Serbaguna Gotong Royong established on November 10, 1957, and Musyawarah Kekeluargaan Gotong Royong (MKGR) established on January 3, 1960. The three organizations were parts of Kelompok Induk Organisasi (KINO), which later established Sekretariat Bersama Golongan Karya (Sekber Golkar) on October 20, 1964.

In the early stage of the New Order, Sekbergolkar was transformed into political party called Golongan Karya (Golkar). One of the chiefs of Partai Golkar of Malang Raya, explained Partai Golongan Karya during the New Order.

"Members of Golkar comprise members of KINO as well as Indonesian armed forces members and government officers and their family members. As the result, Golkar does not have direct linkage with its members or constituents. Its linkage is with KINO, and KINO is organization that has linkage with its constituents. Since KINO is a part of Golkar, individual member of KINO automatically becomes member of Golkar."

It is evident that Golkar was established and developed by KINO, an organization instead of an individual; Poguntke (2002) categorized this as membership organization-based organisational linkage. Leaders of each KINO are responsible for controlling the organization and become cadre of the party in the future. Another chief of Partai Golkar of Malang Raya emphasized that:

"Golkar does not depend on one central figure, instead it is belongs to cadres of organization. Our concept is different from that of other political parties. Golkar emphasizes on structure of its organizations. Since it was first established, Golkar believes that the highest decision-making is one obtained through forum. There are several forums in thus party. The first is national forum (MUNAS), provincial forum (MUSDA), city and municipality forum (MUSDA), region-level forum (MUSCAM), sub-region level forum (MUSLUR), and the last is establishment of cadre groups (POKAR)."

Thus, Golkar does not have any central figure that has ultimate power in decision-making. Based on Mack (2010)'s typology, Golkar is categorized as elite or cadre parties. In addition, in this party, structure of organization and organizational mechanism is central in its process. As the result, linkage between Golkar and its constituent is relatively stable.

\subsection{Ideological or pragmatic linkage between political party and constituent}

The chief of Golkar of Malang Raya stated that the party has never encountered any issues related to ideology. Starting from its establishment to the New Order to Reformation Era, the Five Pillars (Pancasila) has become the ideology of this party. "The Five Pillars has always become our ideology, and thus, we have never encountered any issues," the chief reiterated. The party encountered some issues once the ideology is transformed into a jargon or motto, namely "Transparent, Resilient, Growth, and Success."

The informant admitted that there is discrepancy in interpretation and implementation of transparent among the party members. He stated that "each member has different interpretation of transparency and as the result, different method to apply the principle. The implementation starts from individual and later to an organization. Everyone should respect the principle."

In relation to linkage between Golkar and constituent, one of the chiefs of Golkar of Malang Raya stated that:

"Constituent see Golkar from their concept of "transparency." The latest trend in our politics is political 'transaction' between political elites seeking popularity and regional head or legislative candidates. Some are acting as sellers, while others are acting as buyers. How about Golkar? I will not say that Golkar is immune to such transactions. The phenomenon may occur in the past. However, recently, it has declined sharply. It is still happening every now and then since nevertheless, this party has a limited budget."

In terms of the recruitment of legislative candidates or regional head candidates, when we look at the party's articles of association and by-laws (AD / ART), we can see some statements that the party allocated 5\% of for independent candidates. This percentage may increase, to a much higher percentage in practice. Some of the party elites took advantage of this condition to conduct political "transactions." This is the example of the discrepancy in both interpretation and implementation of "transparency" among the party cadres. Andre and Beyens (2013) claimed that such discrepancy may result in friction between elites and constituents. A Chief of Golkar justified this phenomenon and stated that:

"As the result, we should be very selective. Our General Election has adopted direct voting system. There are independent candidates, especially public figures who will attract many voters. They are popular and have a solid base. If we want to increase our votes by $5 \%$, we should support these candidates. However, 
we have never forced the party's principles and perspective to these public figures. Such decision may trigger conflict and friction."

The $3^{\text {rd }}$ Article of Partai Demokrat's articles of association and by-laws stated that the party's ideology is religious nationalism, namely working hard to fight for public interest, moral values and religion, as well as nationalism, humanism and pluralism. Furthermore, Article 4 of the document mentioned Tri Pakca Gatra Praja that means three principles, democracy, prosperity and security to build the nation. This results in one follow-up question, to which extent has this ideology been implemented among the party members? One of the chiefs of PD of Malang Raya responded to the question as follows:

"Tri Pakca Gatra Praja has yet been implemented well among the party members. We should spread more information about the philosophy. We are a new party and thus, need some training to increase loyalty and fanatism of our cadres. We are still lacking on these areas. Thus we should talk about local and central figures. We have encountered a lot of obstacles. As an example, regional heads from Partai Demokrat have yet been able to apply Tri Pakca Gatra Praja. It is an on-going process and we are striving to achieve our goals."

The lack of ideological ties between constituents and cadres and an ineffective organizations categorized PD as parti personalistic linkage, according to Roberts (2014) typology. Under such conditions, neither ideological nor programmatic debates takes place in PD. One of the chiefs of PD of Malang City illustrated the party's program to spread the party's ideology and obstacles the party experienced.

"We focused on political ideology that strengthen political party of this party in sub-regional, regional and city level. Unfortunately, we have to swallow a rather hard pill that our seat acquisition in the House of Regional Representatives of Malang City declined from 12 in 2009 General Election to 5 in 2014 General Election. Despite of such decline, we are still on the $4^{\text {th }}$ position in Malang City. We have one chair in each regional in Malang City which means we still can voice our interests of our constituents from the regions. We can have contributions toward policy issued by the government of Malang City."

Article of associations and by-laws of PDIP comprises a lot of things related to principles and teachings, namely Bung Karno's philosophy doctrines, the party's identity, and characters. Article 5 stated that the party based on the Five Pillars stated in the Preamble to the 1945 Constitution of the Republic of Indonesia. In addition, it also stated that identity of the political party included nationality, democracy and social justice, and the party is associated with mutual cooperation, democratic, independent, unyielding, and revolutionary progressive. This information raised one question that is how PDIP introduces and spread information about these many values to non-member cadres, members, and voters. One of the chiefs of PDIP of Malang City explained that:

"This party has a lot of philosophies. For example, ideology starting from the Five Pillars and their actualization, and Soekarno's philosophy, Trisakti (three pillars). These should be embedded to all legislative candidates so that they use these references during policy making and in supervising the city government. Besides that, we also conduct discussions about our ideology to anyone interested in it. Everyone is welcome to the discussion."

In this ideological context and these values, PDIP is substantially known as the party for oppressed individuals. Discrepancy between ideology and value in textual context appears with the realization the party's ideology and values among constituent communities and PDIP supporters. The most challenging issue is related to how PDIP introduces these values to young people, non-active member of the party so that although they are neither an active members or member of the party, they still have inner or ideological ties to the party. This fact clearly shows that in line with Roberts' (2014) typology, PDI-P is categorized as programatic linkage type party. One of the administrators of PDIP in Malang Raya elaborated what efforts the party has made:

"We usually conduct discussions in our branch offices or within regional-scale. There are 9 management staffs in each of branch offices and they usually invite community members, head of community groups $(\mathrm{RT} / \mathrm{RW})$ when the legislative members visited the office. This has become a routine our internal structure or when the House is in recess. Management staffs, like I, come to the discussions, but the House is in recess the legislative members attend the discussions and talk about our visions and the government program. Objective of those discussions is to spread influence of the legislative members and regional heads from PDIP to the community."

The role of local kyai in PKB in Malang city is quite ardent. Some of these local kyai have wide communities coverage. Yet some others kyai have limited area of community, from which Abdurrahman Wahid perhaps has got his title as the "village kyai". These local kyai have a direct relationship with the community or constituents at the base level of a political party. They, with their religious authority, will bring the aspirations of the people as per their choice. Such a relationship character that come about between the constituent, local kyai, and elderly kyai towards PKB clearly places PKB in the typology of personalistic linkage and charismatic bond (Roberts, 2014).

In fact, it is not uncommon for these local kyai being loyal followers of elderly kyai or figures from certain 
political parties who have wider range of influence, with the intention that the people aspirations will then be determined by which these elderly kyai are channeled in. Formerly, in the presidential election, governor election, and mayor election, this kind of practice is existent. A statement by a PKB official in Malang Raya reinforces this trend.

"In NU, Kyai's words are of importance. Usually when a Kyai mentions the name of a figure who is eligible to be elected to represent PKB, the constituents will automatically abide by. So in essence, we actually did not go down directly on the PKB management in Malang Raya, but we took advantage of certain figures who in our opinion had a strong mass base. And those figures are local kyai".

\subsection{The process and intensity of political education programs carried out by political parties to constituents}

How do Golkar party introduce their values to the public, especially among today's millennial youth who do not know about Golkar in former times? And those who know Golkar in the past probably have a different view on what Golkar is today. What is Golkar doing, then? The following is an explanation from a Golkar party official in Malang Raya.

"At this moment in the digital era, we use the internet or social media which are managed by young people whose aspirations are channeled to us. They are the new generation in Malang. The new generation who wants to raise Golkar is the first thing to get going. Second, forming a community of young people, where we provide political insights, political education about Golkar. There are various communities, including a community of mountain climbers and a community of hawkers. We provide lessons and education related to Golkar, which hopefully will benefit the party. There is also a religious activity community, as well as a community of young mothers. This activity continues to be reiterated on social media and on YouTube ".

According to Golkar officials, the activities of utilizing and fostering collateral organizations and membership organizations (Poguntke, 2002) are continuously carried out while consistently disseminating Golkar to the wider community. This makes Golkar into a clientelist linkage typology (Roberts, 2014). Career paths also remain on track. With such measures, the board has an optimism that among constituents, Golkar is a party that ought to be supported.

How does Golkar socialize its ideologies or programs to the constituents? It appears that Golkar, which is a pungent party from the New Order era, still has a strong party structure. It is still, whether being admitted or not, using the patronage pattern with the bureaucracy (Roberts, 2014). This is the thing that Golkar board in Malang Raya continues to take on, as stated by its member:

"We, Golkar party, always go down to bring up our constituents. That is through the leadership of the board from sub-district level to village level. Once a month the heads of sub-district leaders hold activities such as a community gathering. They gather at the house of one of the sub-district leaders, and usually there is a Regency / City leader who presents to give advices and encouragement".

Unlike Golkar, PD is less intensive in grounding its ideological values both internally and to audiences outside the party. Introducing ideology is a quite difficult issue for PD. In that sense, the lower level constituents of society supporting this party do not really care about ideology. They only see figures, both central figures and local figures. Therefore, as per PD, the issue of ideological values is more as bits and pieces in cadre process including the recruitment process from partisan to party members.

Regarding the relationship between PD and its constituents, direct interaction is a priority. PD still believes that in Malang Raya, to be particular, the most favorable interaction for election issues is direct interaction. This is especially true for party figures who are more or less known to the public, face-to-face activities with interviews, shaking hands and simply having coffee with the community. Those doings are considered effective as a means of communication. This is as stated by one of the PD management in Malang City as follows.

"Those whom we consider as figures and those who can indeed join us as members, will be included in the party structure. As for now we have 5 members of the board, all of them do have constituents. At least at the local level, we will continue to strive to find such figures at the local level. We ask the heads of subbranch administrators, who have the structural administrators to do that. This is to make easier for us finding votes later."

For the reason that PD prioritizes direct interaction (direct linkage) in dealing with constituents, PD, thus, does not consider the importance of organizational linkage of two types of antithetical relationships as stated by Poguntke (2002). This can be seen from the details stated by other PD administrators:

"It was only recently that we realized the importance of wing organizations, so we tried to establish MudaMudi Demokrat, Angkatan Muda Demokrat, and Srikandi Demokrat. But again, to strengthen each of these wing organizations, we notice that there is a need for a central figure in each organization. Therefore, SBY, as a central figure in $\mathrm{PD}$, began to generate new figures who were expected to become central figures in each of these wing organizations".

In addition, cadre levels in PD are also not strictly regulated. The regeneration process in PD allows for 
leaps and bounds from someone who was previously not ready to be, but who can eventually be positioned in the legislative body at the regional, provincial and central levels. This shows that in PD, anyone has the opportunity to occupy an important position, both in the party structure and in the legislative body as long as that person fulfills the parameters set by the party. A PD administrator in Malang explained:

"So you see, we agreed that the nomination of legislative members would be at the lower level. Even though the current electoral system does not look at ballot numbers, but internally in each party, ballot numbers are a problem. Because they still have the assumption that ballot number 1 is the best among other ballot numbers. This makes us in the party to apply a such assessment. So that number one in our opinion is the best. How loyal he has been to the party, how long he has been a cadre, and what he can do, those things are our judgment".

The regeneration process in PDI-P according to the household budget is normatively carried out in stages. Primary regeneration is at the Branch Leadership Council level, that is in City / Regency level, intermediate regeneration is at Regional Leadership Council level, that is at the provincial management level, then the main cadre is at the Central Executive Council level, that is at the national level.

In maintaining relations with constituents, it seems that what has been done by PDIP is not much different from Golkar has. First, by using party structure line when meetings are held at the branch level. Such meetings usually do not only invite party members, but also a number of party constituents and sympathizers so that they can get to know more about what PDIP is. Second, through faction members on the council. During recess they are encouraged to go down to their respective constituencies to meet and have dialogue with their constituents. And third, through official party events, for example at the PDIP anniversary, branch managers were asked to invite a certain number of constituents to attend. This is explained by a PDIP branch administrator:

"At party birthdays, for example, branch administrators are invited to bring 50 people outside of the branch administrator. Why does the branch administrators become the one inviting them? This is because the branch administrator should know those who are supportive to our party. That is our way to maintain by having them attending any party moments. Including the commemoration of 1 June as the birthday of Pancasila, as well as the 17 August celebration".

In PKB, according to Article 31 (1) of the household budget, there are also a number of autonomous bodies, which among others function is to implement party policies, especially those related to certain community groups which is a mass base and source of party cadres in various segments and / or social strata of society. However, as stated by the Head of PKB Malang City, in NU culture - which is the sociological basis of PKB -, the figures who hold leadership in autonomous bodies have high compliance to kyai who happens to be their respective role models. A PKB leader in Malang Raya affirmed the following word.

"We know that NU is the founder of PKB, and PKB's mass base is in NU. In NU culture, the NU masses are very obedient to Kyai. Meanwhile, in NU and PKB, there are a number of autonomous organizations which are generally led by figures who have close relations with particular kyai. So in fact, these autonomous bodies are one of the strongholds power that support the existence of PKB, because that's where we build communication with the masses of our constituents".

With such a culture and sociological basis, it generates PKB into a type of organizational linkage based on membership organization (Poguntke, 2002) and personalistic linkages and charismatic bonds (Roberts, 2014).

\section{Conclusion}

Among the four political parties studied based on the prevailing characteristics, it can be identified as follows. The types of clientelist linkages parties are: Indonesian Democratic Party-Struggle (Partai Demokrasi IndonesiaPerjuangan / PDI-P), Democratic Party (Partai Demokrat / PD), and Functional Groups Party (Partai Golongan Karya / Golkar); the encapsulating linkages political party is National Awakening Party (Partai Kebangkitan Bangsa / $P K B$ ); the programmatic linkages type is all of the four political parties studied; the personalistic linkages or charismatic bonds types are National Awakening Party (Partai Kebangkitan Bangsa / PKB) and Indonesian Democratic Party-Struggle (Partai Demokrasi Indonesia Perjuangan / PDI-P); and political parties with marketing linkages typology is Democratic Party (Partai Demokrat / PD).

All political parties studied using autonomous bodies or wing organizations in building relationships with their members / constituents and society. These organizations can be formal in nature, in the sense that they have an attachment to the management structure of the political party concerned or are non-formal in nature, which means that the association is only based on certain interests or activities that are incidental in nature.

With these political parties having autonomous bodies or wing organizations, it is possible for each political party to establish relationships with parties outside the political party, including non-governmental organizations, in an effort to empower the community to increase participation. Speaking of which, the political parties with the encapsulating linkages typology (in this case is $\mathrm{PKB}$ ) are the most likely to do so. This is because political parties of this type have clearer ideologies and identities, as well as more loyal cadres and constituent bases, so that they are likely to have more commitment in carrying out the function of articulation and aggregating the 
interests of society. But that does not mean that political parties with other typologies are unlikely to do so. They might have greater risks compare to the encapsulating linkages typology party, for example inviting the practice of money politics, political patronage, or the apprehension that these activities will only run temporarily.

\section{Acknowledgements}

This research was sponsored by the Ministry of Research and Technology / National Research and Innovation Agency, Deputy for Strengthening Research and Development based on Decree Number 8 / E1 / KPT / 2020, dated January 24, 2020. For that, the authors would like to thank you. The author's thanks also go to colleagues in the Department of Public Administration and fellow researchers at The Institute of Research and Community Service University of Merdeka Malang. With their support, this research went well.

\section{References}

André, A., Depauw, S., \& Beyens, S. (2013). "Party loyalty and electoral dealignment". Party Politics, 21(6), 970-981. doi:10.1177/1354068813509521

Almond, G.A. (1974). "The study of comparative politics", in Comparative politics today: A world view, edited by Almond, G.A., Boston, Little Brown \& Company

Biezen, I.V. et al., (2012). "Going, going, . . gone? The decline of party membership in contemporary Europe", European Journal of Political Research, 51: pp. 24-56, 2012 doi: 10.1111/j.1475-6765.2011.01995.x

Budiardjo, M. (2008). Dasar-dasar Ilmu Politik. Revised Edition, Jakarta, PT Gramedia Pustaka Utama

Chadwick, A. dan Stromer-Galley, J. (2016). "Digital Media, Power, and Democracy in Parties and Election Campaigns". The International Journal of Press/Politics, 21(3)

Creswell, J.W. (2010). Research Design Pendekatan Kualitatif, Kuantitatif dan Mixed, Third Edition, (translated), Yogyakata, Pustaka Pelajar

Cumming, Jr., Milton, C., dan Wise, D. (1981). Democracy Under Pressure An Introduction to the American Political System, Fourth Edition, New York, Harcourt Brace Jovanovic, Inc.

Dalton, R.J. (2011). Political parties and democratic linkage, How parties organized democracy, Oxford University Press, New York

Drummond, A.J. (2006). "Electoral volatility and party decline in western democracies: 1970-1995", Political Studies: 2006 Vol. 54, Political Studies Association

Ehin, P. dan Solvak, M. (2012). "Party voters gone astray: explaining independent candidate success in the 2009 European elections in Estonia", Journal of Elections, Public Opinion and Parties, Vol. 22, No. 3, 269-291, August, http://dx.doi.org/10.1080/17457289.2012.682579, Routledge Taylor \& Francis Group

Ezrow, L. dan Hellwig, T. (2014). "Responding to voters or responding to markets? Political parties and public opinion in an era of globalization", International Studies Quarterly, Vol. 58, International Studies Association.

Gunther, R. dan Diamond, L. (2003). "Species of political parties a new typology", Party Politics, Vol 9. No. 2 pp. 167-199, SAGE Publications, London.

Heidar, K. dan Saglie, J. (2003). "A decline of linkage? Intra-party participation in Norway,1991-2000", European Journal of Political Research 42, Oxford, Blacwell Publishing, Ltd.

Mack, C.S. (2010). When political parties die: a cross-national analysis of disalignment and realignment, Santa Barbara, California, Praeger.

Macridis, R.C. (1996). Pengantar Sejarah, Fungsi dan Tipologi Partai Politik, In Amal, Ichlasul (ed), Teori-Teori Mutakhir Partai Politik, Yogyakarta, PT Tiara Wacana Yogya

Mas'oed, M. (2004). Jangan Kubur Partai, Kompas, 24 September

Norris, P. (2005). Political Parties and Democracy in Theoretical and Practical Development in Party Communications, National Democratic Institute for International Affairs (NDI)

Poguntke, T. (2002). "Parties without firm social roots ? Party organisational linkage”, Working Papers 13, School of Politics, International Relations and the Environment (SPIRE), Keele University UK, http://www.keele.ac.uk/depts/SPIRE/

Prianto, B. (2010). "Relasi organisasi non pemerintah-partai politik dalam penguatan partisipasi publik di kota Malang", JIANA, Jurnal Ilmu Admiistrasi Negara, Terakreditasi SK Dirjen Dikti, No. 65a/DIKTI/Kep/2008, Vol. 10, Nomor 1, hal. 48-68

Prianto, B. dan Noorsetya, B. (2016). "Implication of declining of political parties image post-election 2014", Public Policy and Administration Research, Vol. 6, No.3, p. 37-41

Roberts, K.M. (2014). "Party-society linkages and democratic representation in Latin America", Canadian Journal of Latin America and Caribbean Studies, Vol.27, No. 53 (2002): 9-34

Selle, P. dan Svasand, L. (1991). "Membership in party oganizations and the problem of decline of parties", Comparative Political Studies, Vol. 23, No. 4, January, Sage Publication, Inc.

Shively, W.P. (1991). Power and Choice an Introduction to Political Science, Second Edition, New York, 
McGraw-Hill, Inc.

Undang-Undang Republik Indonesia Nomor 32 Tahun 2004 tentang Pemerintahan Daerah.

Undang-Undang Republik Indonesia Nomor 12 Tahun 2008 tentang Perubahan Kedua atas Undang-Undang Nomor 32 Tahun 2004 tentang Pemerintahan Daerah

Undang-Undang Republik Indonesia Nomor 2 tahun 2011 tentang Perubahan atas Undang-Undang Nomor 2 Tahun 2008 tentang Partai Politik

Undang-Undang Republik Indonesia Nomor 8 Tahun 2015 tentang Pemilihan Gubernur, Bupati, dan Walikota

Tempo, 21 Mei 2017

http://cakmaryono.com/malang-raya/ 